\title{
The Integration of the Authority of Judicial Institutions in Solving General Election Problems in Indonesia
}

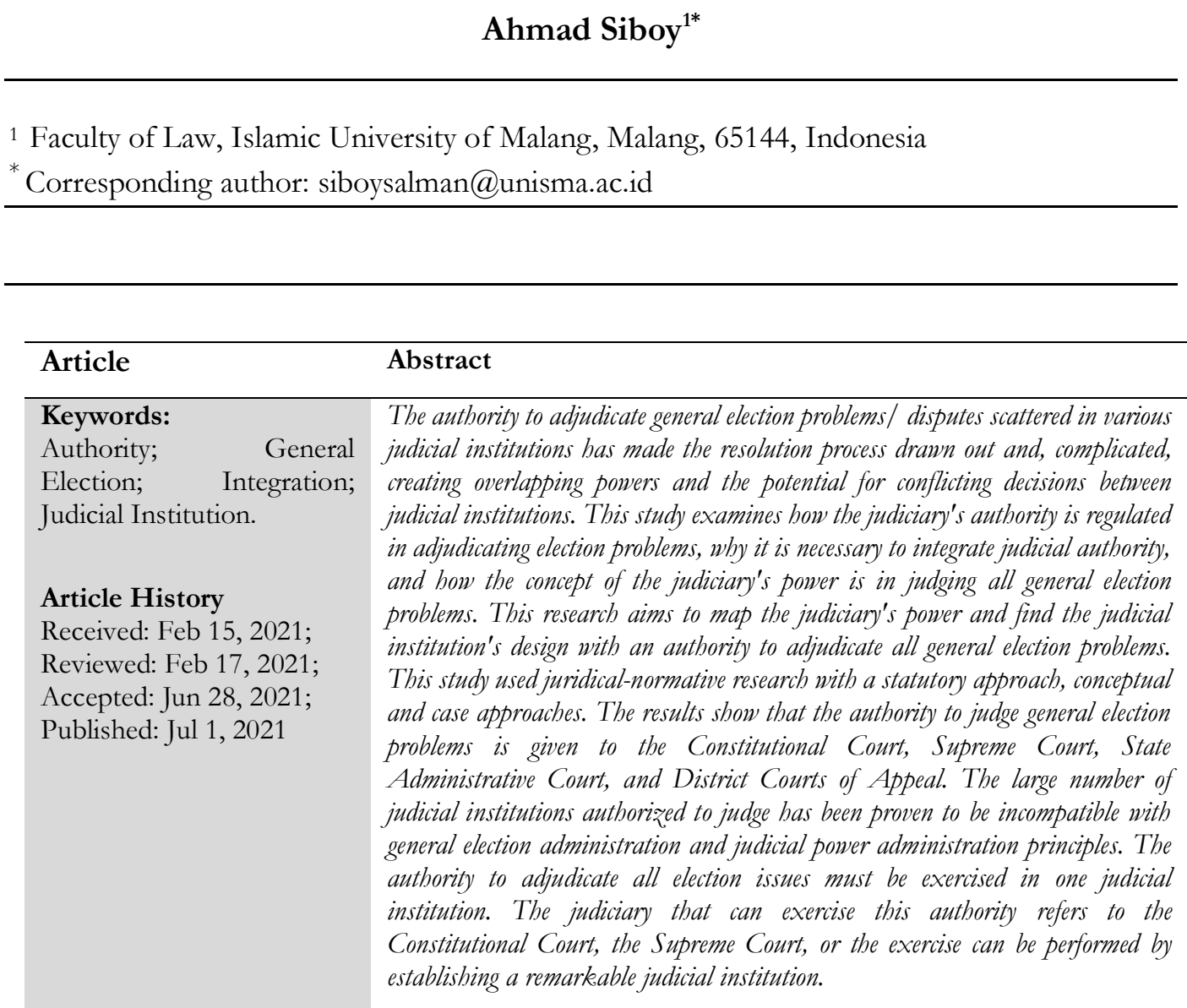

(C2021; This is an Open Access Research distributed under the term of the Creative Commons Attribution License (https://Creativecommons.org/licences/by/4.0), which permits unrestricted use, distribution, and reproduction in any medium, provided the original works is properly cited.

\section{INTRODUCTION}

General elections are a concrete form of the implementation of constitutional democracy in Indonesia. Through general elections, all citizens can exercise their sovereignty in the form of the highest right to be elected and to vote (Olsson \& Meek, 
2013; Pal \& Gonawela, 2017). As a constitutional democracy, Indonesia's general elections must hold direct, public, free, secret, honest, and fair elections (Al-fatih, 2020).

Various electoral formulations have always been improved from period to period, at the level of both the electoral process and electoral laws. The electoral process is related to the mechanisms implemented in the implementation of elections, such as nominations, registration, campaigns, counting methods, determination of results, etc. (see Assistance, 2011; Leuprecht \& Skillicorn, 2016; Luttig \& Motta, 2017).

Meanwhile, electoral laws are related to the general election system and regulations governing how elections are run and distributed. Rae explains electoral laws as "those which govern the process by which electoral preferences are articulated as votes are translated into the distribution of governmental authority (typically parliamentary seats) among competing political parties" (Al-fatih et al., 2014)

However, various general election formulations in Indonesia are always accompanied by multiple problems, including ethical, administrative, and even criminal issues. Every general election is accompanied by various questions, ranging from the nomination process to the vote count. This condition occurs because the infrastructure and superstructure of the general election are still low.

The general election's performance is to minimize and resolve various problems/ disputes during the election implementation. It is also accompanied by the formation of particular institutions that supervise the performance, such as the Election Supervisory Board (henceforth Bawaslu) (Esfandiari \& Fatih, 2020) and the Honorary Council of Election Administrators (henceforth DKPP). Also, judicial institutions are given the authority to adjudicate problems/disputes that arise during the implementation of the general election, namely the Supreme Court and the Constitutional Court.

The institutions established to handle election problems/disputes have also been given the qualification of their respective powers for each institution according to the types of conflicts in general elections.

Given different powers for each institution that adjudicates various election disputes is a relatively positive thing considering that each conflict in the election has its own space according to the type of violation. If the offense is related to the nomination process, the process can be submitted to the State Administrative Court. Suppose Election organizers commit ethical violations, both the General Election Commission (henceforth KPU) and Bawaslu. In that case, it can be processed by the DKPP. Meanwhile, problems related to disputes over the results of general election disputes can be submitted to the Constitutional Court.

By this sorting, each judicial institution can only focus on processing election problems under its authority to only rely on one institution. Besides, the large number of institutions that have the power to adjudicate the general election process can also 
prevent its court's concentration in one institution. If there is one general election institution that is problematic, other institutions are still transparent.

However, these institutions' presence creates new problems in the general election, such as the discrepancies in the decisions between one judicial institution and a lengthy judicial process. It is often slow to provide fair legal certainty for the people who seek justice. In this case, it can be seen from the process at the Supreme Court and the Constitutional Court in the implementation of the 2009 General Election regarding the calculation of seats in the House of Representatives where the Supreme Court and the Constitutional Court have different decisions regarding the number of seats obtained by each political party (Siboy, 2013). Even in terms of examining laws and regulations related to elections, the Supreme Court and the Constitutional Court often issue conflicting decisions. For example, in the Supreme Court and the Constitutional Court decisions in terms of regulations regarding the requirements for candidates for members of the Regional Representative Council someone who is a member of a political party. Based on this condition, the examination fell on the judiciary's regulation in adjudicating general election problems and why it is necessary to integrate authorities to judge its problems. Then, the concept of alternative judicial institutions can be used as a judicial institution that is authorized to adjudicate all of the issues. This research offers findings in the form of integrating the judiciary's authority as a solution to overcoming overlapping powers and legal uncertainty over regulations regarding the resolution of election problems. The integration of authority in one judicial institution is an alternative to the pattern of dispute resolution in the Indonesian legal system, which tends to ignore the slices of the object of the dispute being tried.

\section{METHOD}

This study uses a type of juridical-normative research or often referred to as doctrinal research. According to Soekanto \& Mamudji (2012), normative legal research examines library materials. The approaches used included a philosophical approach, a statutory approach (Schane, 2002), a conceptual approach (Elliott \& Timulak, 2015), and a case approach. Sources of legal documents consisted of primary legal, secondary legal, and legitimate tertiary sources (Momeni, 2012; Pennisi, 2016; Sinha, 2015). The primary legal materials source consisted of laws and regulations and judicial decisions related to this research theme. Secondary legal material sources comprised books and journals. Besides, tertiary legal materials were in the form of Kamus Besar Babasa Indonesia. The legal materials were then grouped and analyzed prescriptively (Peter Mahmud Marzuki, 2014).

\section{RESULTS AND DISCUSSION}

Map of the Authority of the Judiciary in Adjudicating General Election Issues 
In terms of solving general election problems, four judicial institutions have different powers, The Constitutional Court, Supreme Court, State Administrative Court, and Local Judicial system.

\section{Constitutional Court}

The Constitutional Court is a judicial institution that can adjudicate disputes over general election results in general elections. It is only authorized to adjudicate disputes over the results of general elections. Disputes over the results of the general election are disputes regarding the determination of vote acquisition. It can affect the position acquisition of the People's Representative Council (henceforth DPR), Regional Representative Council (henceforth DPD), and Regional People's Representative Council (henceforth $D P R D$ ) for each political party participating in the election. The second election results in disputes over-determining the vote acquisition result of the national presidential and vice-presidential election.

The settlement process is divided into two different things. The difference lies in the subjectum leti and objectum letis (Siahaan, 2011), process, and completion time. Subjectum letis or parties that can submit disputes over legislative elections are general election participants for the People's Representative Council (henceforth DPR), the Regional People's Representative Council (henceforth DPD), and the Regional People's Representative Council (henceforth $D P R D$ ). They propose a cancellation request to the Constitutional Court.

Chart 1. The Flow of Dispute Resolution on Legislative Election Results (source:

Cahyandari et al., 2020)
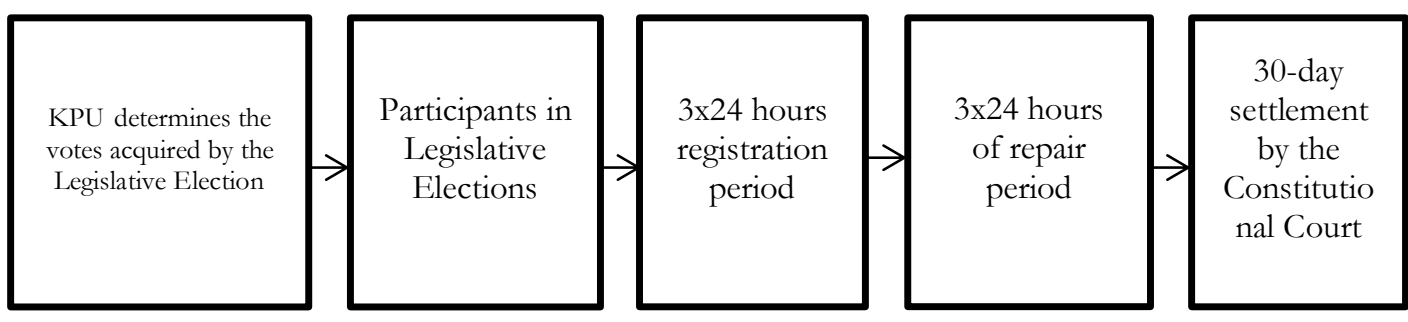

The presidential and vice-presidential candidate pair can propose canceling the votes acquired by the election results within three days after the General Election Commission decision regarding determining the election results' votes. The Constitutional Court then decides the petition's outcome for fourteen days from the appeal's receipt.

Chart 2. The Flow of Dispute Settlement on the Result of the Presidential / Vice-

Presidential Election (source: Cahyandari et al., 2020)

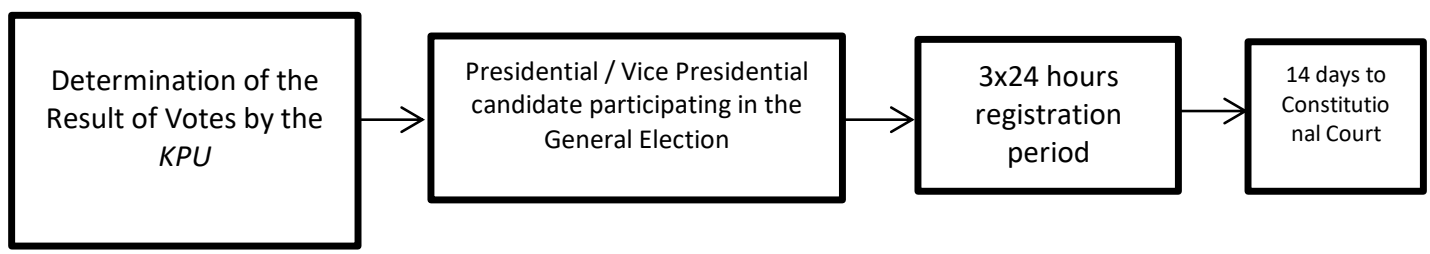


The Constitutional Court's authority in adjudicating disputes over general election results is a dispute that is directly attributed to the constitution, namely in Article 24C of the 1945 Constitution of the Republic of Indonesia. When the Constitutional Court tries disputes over election results, these cases' legal process will automatically only occur once or at one instance. This condition occurs because the Constitutional Court is a judicial institution at the first and last instance. In the Constitutional Court's judicial process, the judge is simultaneously at the judex facti and judex juris. The Constitutional Court's verdict is final and appeal, or there are no more legal remedies against the Constitutional Court's decision regarding dispute cases over the general election results (Tatawu, 2017).

\section{Supreme Court}

The Supreme Court is one of the judicial institutions that can adjudicate problems/disputes in general elections. It judges at the cassation level, so in adjudicating election administrative violations, the Supreme Court becomes the first and last instance of judicial institution. Administrative violations include violations of the procedures or mechanisms related to administering the election's implementation at every general election stage. Still, these violations do not cover election crimes and breaches of the code of ethics.

Chart 3. The Election Administration Violation Settlement Flowchart (source: republik indonesia, 2017) 
Bawaslu receives, checks, reviews, and recommends to the KPU

The KPU is obliged to carry out Bawaslu's Recommendations through the Issuance of its Decrees

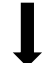

Candidates for members of People's Representative Council, Regional Representative Council, Provincial Regional Representative Council, Regency / City Regional People's Representative Council, for who have been granted administrative sanctions for cancellation as election participants may submit legal remedies to the Supreme Court.

Candidates for members of People's Representative Council (henceforth DPR), the Regional People's Representative Council (henceforth DPD), and the Regional People's Representative Council (henceforth DPRD) for who have been granted administrative sanctions for cancellation as election participants may submit legal remedies to the Supreme Court.

The Supreme Court's decision on the settlement of administrative, general election violations is final and appeal as stated in Article 463 paragraph (8) that "The Supreme Court's decision is formal and appeal. In this election administrative violation, the Supreme Court becomes the judicial institution at the first and last instance. It is different from its authority in adjudicating general cases where one is a judicial institution that only judges at the cassation level. One means that the Supreme Court can only try an issue tried in the judicial process at the judex factie level. At the judex factie level, judicial institutions are carried out under or within the Supreme Court, namely the court of the first instance (located in a district or city) and at the appellate court (located at the provincial level). It is a problem in itself. The Supreme Court is a judicial institution that can only judge at the level of judex juris or different from the Constitutional Court, which can judge at the judex factie and judex juris stages simultaneously.

When the Supreme Court adjudicates direct election administrative violations at the level of the judex juris, then, of course, this is not easy to justify in terms of legal logic. The judicial process must be tried by the judex factie first because it is at this judex 
factie level that the preliminary examination and evidence will be tested so that the judge can decide according to the trial's facts. Whereas in the judicial process at the judex juris level, the Supreme Court only examines the judges' law's application at the judex factie level.

Therefore, how can the Supreme Court directly decide at the judex juris or the law's application while examining the facts of election administrative violations has not been carried out? On the other hand, the judicial process's argument can be submitted directly to the Supreme Court or without going through the judicial process at the first instance and appeal. Because administrative violations of the general election have been processed in the Election Supervisory Board (Bawaslu), arguments cannot be justified. The process carried out at Bawaslu for administrative violations cannot be said to be a law enforcement process or due process of law, which can be equated with a trial process at court of first instance and appeal. There are two very absolute differences in Bawaslu and the judicial process under the Supreme Court. First, the judicial processes carried out by judicial institutions under the Supreme Court, such as the District Courts and the High Courts are judicial processes carried out by institutions that are structurally controlled by power and institutions under the auspices of the Supreme Court. Meanwhile, the Bawaslu is not a judicial institution within the structure and institutions within the Supreme Court.

Second, position and authority. Judicial bodies at the First Instance and Appeal, such as the District Courts and High Courts, are institutionally positioned to exercise judicial power to enforce law and justice. Meanwhile, the Bawaslu is not an institution to enforce law and justice but rather as an election administering institution.

Thus, it can be stated that since the beginning of its formation, Bawaslu is not an institution that is domiciled in the branch of the judicial power, so that it is unable to exercise its law enforcement authority (law enforcement).

Third, the difference between the judicial process and the administrative process; administrative violations committed by the Bawaslu before being tried or submitted to the Supreme Court constitute an administrative process, not a legal remedy. Organizational efforts and legal remedies are two different things. Legal action means the space provided for people who seek justice and feel disadvantaged to fight for their rights through the process in court. Legal action is necessary for people seeking justice as a form of legal protection. Legal remedies can take effect when the $\dot{f}$ verdict from a panel of judges is deemed to have an error that is considered detrimental to the parties in the case (Yuslim, 2015). Wiyono (2008) defines legal remedies as a form of legal protection for the people for government actions that violate the law (rechtbescherming van de burger tegen de overbeid beschikkingen). Legal remedies become an instrument or a means to correct mistakes in previous decisions. The legal remedies themselves are divided into ordinary remedies and extraordinary remedies. 
Meanwhile, administrative efforts are defined as efforts that are processed administratively by government agencies. According to Soemaryono, an administrative effort is a complete assessment of a state executive decision regarding legality (rechtmatigheid) and opportunity (doelmatigheid) (Soemaryono \& Erliyana, 1999). Organizational measures are divided into two, namely administrative objections and administrative appeals. The administrative appeals, namely the settlement of state administrative disputes, are carried out by the superior agency or other agencies from issuing the disputed decision. The objection procedure is that the settlement of state administrative disputes is carried out by the agency issuing the decision concerned (Ridwan, 2009).

Table 1. The Differences between Judicial and Bawaslu Institutions

\begin{tabular}{llll}
\hline No & Distinguishing Parameters & Judicial Institution & Bawaslu \\
\hline 1 & Institutional & $\begin{array}{l}\text { Being within the Supreme } \\
\text { Court }\end{array}$ & Independent \\
2 & Position and Authority & $\begin{array}{l}\text { The executor of the } \\
\text { judicial power has the } \\
\text { authority to judge a } \\
\text { case/dispute. }\end{array}$ & $\begin{array}{l}\text { Election } \\
\text { Administrators }\end{array}$ \\
& & $\begin{array}{l}\text { Adjudicating Legal } \\
\text { Remedies }\end{array}$ & Handling \\
& Legal Efforts and & Administrative & Efforts \\
\hline
\end{tabular}

(source: Liany, 2016)

\section{The State Administrative Court}

The State Administrative Court is a judicial institution hierarchically under and within the Supreme Court. As an institution under the Supreme Court's environment, automatically, the State Administrative Court is an institution that can exercise judicial power, namely an institution that attributively has the function of enforcing law and justice. If a hierarchical power and institutional approach are used, the State Administrative Court is a judicial institution first or in regencies and cities. Regarding resolving general election problems, especially regarding the process disputes as regulated in Chapter II Article 466-471 of Law number 7 of 2017 concerning general elections, the State Administrative Court becomes a judicial institution with no decision and institutional relationship with the judicial institutions above it. It can be seen from the State Administrative Court's legal construction's authority in settlement of Election Process disputes. Article 469 states that the Bawaslu decision regarding the payment of Election process disputes is a legally appeal and appeal decision, except for decisions on general election process disputes relating to: 
Article 469 states that Bawaslu's decision regarding dispute resolution in the election process is a final and binding decision. However, the Bawaslu Decision, which is final and binding, is excluded from the Bawaslu decision in matters relating to:

a. verifying general election contesting political parties;

b. determining the list of candidates for members of DPR, DPD, Provincial DPRD, and Regency / Municipal DPRD; and

c. Selecting candidate partners.

Suppose the general election process dispute settlement is referred to in paragraph (1) letter a. In that case, letter b, and letter c is not accepted by the parties, they (political party, initiate for DPR, DPD and DPRD) may submit legal remedies to the state administrative court.

The state administrative court examines and decides the lawsuit as referred to in article 469 letter a, letter b, and letter c, no later than 21 working days after the case is declared complete. The state administrative court's decision is formal and appeal, and no other legal remedy is possible.

Chart 4. The Legal Construction on the Flow of Election Process Dispute Resolution (Source: republik indonesia, 2017)

Bawaslu receives applications for dispute resolution during the general election process

Legal Remedies to the State Administrative Court by the Parties In terms of verification of political parties, determination of legislative candidate members, and determination of president / vice president candidates.

The State Administrative Court will judge within 21 days

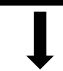

The Administrative Court decision is final and appeal.

The administrative Court decision is final and appeal baiding or there is no attempt at retrial or appeal and cassation.

The chart regarding the stages of resolving the general election process dispute, the State Administrative Court's absolute competence, has no institutional relationship and decisions with the judicial institutions above it. One has no institutional relationship with the institutions above it, the High State Administrative Court and the Supreme Court. When the High State Administrative Court decision is final and appeals to the general election process's dispute. It is precisely the same as stating that 
the High State Administrative Court is a judicial institution whose judgment cannot be corrected by judicial institutions above it.

\section{District Courts and High Courts}

District Courts (Regency or City level judiciary institutions) and High Courts (Provincial level general courts) are judicial institutions that are also given the authority to become one of the judicial institutions authorized to adjudicate issues in general elections. The authority is to investigate, judge, and decide general election crimes. One is a criminal act of violation or crime as regulated in the Law on General Elections. The settlement process for general election violations or illegal actions is subject to Law Number 8 of 1981 concerning Criminal Procedure Law, except for the process which must be initiated through coordination with the Integrated Law Enforcement Center (henceforth Gakkumdu) first. One can be seen through the following chart below:

Chart 5. The Flow of General Election Criminal Violation Resolution (source: republik indonesia, 2017)

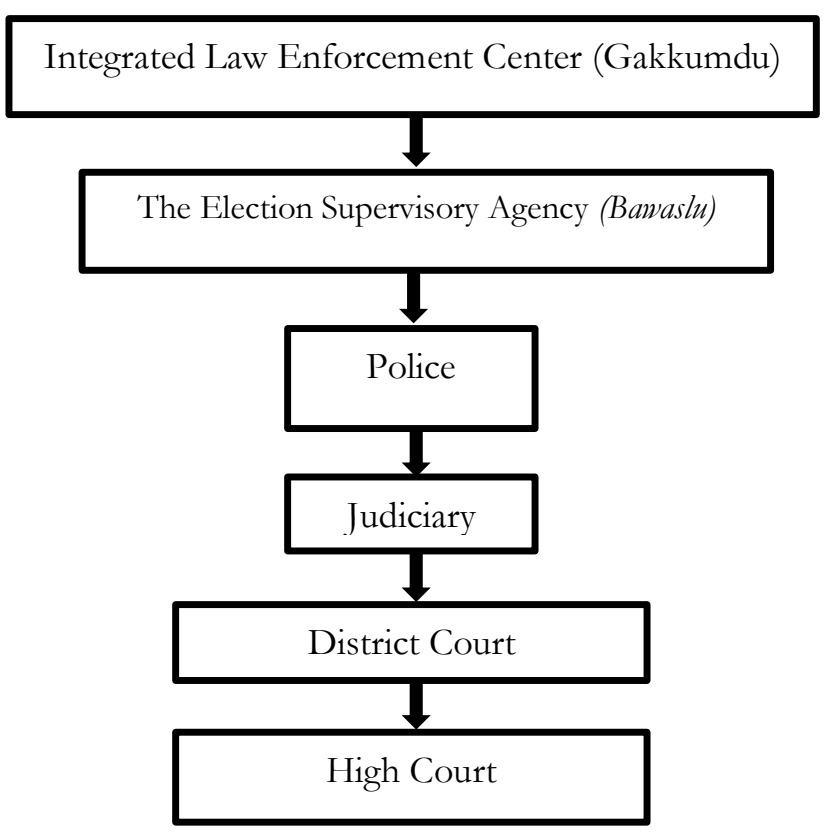

From the chart above, it can be seen that the trial process at the High Court is the last instance of the judicial process. It means no other legal remedies include appeal and judicial review to the Supreme Court. In resolving general election violations and criminal acts, the judicial process only reaches the judex factie process, even though it is carried out in two stages. One is because, even though a case has been tried at the first instance and then an appeal is filed, the court of the first instance and appeal has the 
same authority, namely to try at the level or stage of the judex factie instead of judex juris. Thus, the legal process for election violations or election crimes does not reach the Supreme Court's cassation process even though the High Court and the District Court are judicial institutions under and within the Supreme Court.

On the other hand, the Constitutional Court cannot adjudicate Election violations considering that the Constitutional Court's authority is limited to adjudicating "election disputes". Thus, decisions on judicial processes for election violations carried out by the Supreme Court may differ from the Constitutional Court's decisions, which adjudicate disputes over results. Even though election violations and result disputes have intersections of objects that influence each other, the decisions cannot be different.

\section{The Urgency of Authority Integration of Electoral Courts}

According to Refly Harun, one problem in solving problems/disputes over the general election results is the number of institutions involved in the election settlement. Overall, Refly Harun raises three main issues in solving general election problems (1). There are too many institutions involved in resolving general election legal problems: Bawaslu, the National Police, the Attorney General's Office, the General Court, the State Administrative Court, the Constitutional Court, and later there will be special regional elections judicial body; (2). The existing courts have limitations in hearing certain electoral disputes, either because the law of the procedure cannot follow the general election process bound by time frames or because of the limited scope of authority; (3). With so many mechanisms and institutions involved, almost all justice seekers cannot recover their violated rights (Harun, 2015).

The problems with the number of judicial institutions in general election settlement can be described as follows:

First, the process of general election problems that does not take place under the same roof makes public understanding and even election participants confused in understanding the types of competencies of each general election judicial institution. For example, the public and even election participants are confused about which institution can judge a case or is being experienced by general election participants. It means people are confused about the right time to complain to the State Administrative Court and the Constitutional Court. Even though the laws and regulations have determined each judicial institution's authority, the public and some participants who do not fully understand the electoral judicial process will have difficulties understanding the kinds of electoral courts in Indonesia. This lack of understanding can confuse election participants about where to complain about the problems they are experiencing.

Second, the judicial process for general elections will tend to be protracted and not simple. It is because one candidate or election participant may proceed in two 
different judicial institutions. As in the case of a pair of candidates whose participation in the General Election Commission has not passed or their participation has been canceled as participants in the general election. The candidate or election participant cannot accept the decision. They accuse the General Election Commission members of committing acts that do not comply with the laws and regulations. In this context, the State Administrative Court will judge the General Election Commission's decision regarding general election participants' determination whether their decision regarding the resolution of candidates or election participants who are not canceled or not passed is in compliance with the provisions of laws and regulations. They violate the conditions of rules and regulations such as applications/ claims submitted by the losing participants.

On the other hand, the general election participants who have not been passed alleges that the election organizer has committed a criminal, administrative violation of the election. They feel that behind the KPU's decision, bribery or other similar acts are committed by political opponents of the election candidates or participants whose candidacy is not passed or canceled by the KPU. So that at the same time, a court is often held in the District Court and even up to the High Court.

Fourth, The electoral regime in Indonesia is divided into national election regimes and regional head elections. National general elections are principally to elect members of the. People's Representative Council (henceforth, DPR), the Regional People's Representative Council (henceforth, DPD), and the Regional People's Representative Council (henceforth, DPRD), and President/Vice President

Meanwhile, the regional head elections elect the governors/ vice governors, Regents / Vice Regents, and Mayors / Vice Mayors. The general election and regional head elections are not held simultaneously or simultaneously due to different electoral regimes. The election that is not random between general elections and regional head elections further exacerbates the electoral justice process's problems. The implementation is considered not to be an integrated electoral system.

The electoral process, which is divided into two models or two regimes, also raises additional problems. The proof is, when there is a debate about who is authorized to adjudicate disputes over the results of regional head elections (henceforth Pilkada), there is a tug of war between the judiciaries. Disputes over the results of regional head elections were tried for the first time by the Supreme Court. In 2008 it was submitted to the Constitutional Court. In 2013 through its decision Number: 97 / PUU-XI / 2013, the Court stated that it was not authorized to adjudicate disputes over the results of regional head elections.

The debate regarding this authority stems from whether the regional head election is part of the general election or the election for People's Representative Council (henceforth, DPR), the Regional People's Representative Council (henceforth, DPD), and the Regional People's Representative Council (henceforth, DPRD), and 
President/Vice President. This debate then culminated in the mandate of the Pilkada law, which delegated the formation of a special judicial body as the institution to adjudicate disputes over the results of the Pilkada. This special judicial body's presence indeed legitimizes the law that regional head elections are a separate part of the election. If the regional head elections are included in the election regime, the Pilkada results' settlement will still be tried by the Constitutional Court.

Of the various problems related to the judicial process towards general elections caused by the number of judicial institutions that judge, this automatically indicates the need to unite or integrate the authorities to adjudicate general election problems into one judicial institution.

The conviction to integrate the authorities to adjudicate general election problems into one judicial institution is based on efforts to avoid potential differences in judicial institutions' decisions, such as disputes over voting results in the 2009 legislative elections. In the division of the Indonesia People's Representative Council's (henceforth, DPR)remaining seats, there were differences in decisions between The Constitution and the Supreme Court. The Supreme Court adjudicates what the absolute competence of the Constitutional Court is.

Although the case in 2009 was purely from the Supreme Court's mistake in understanding its authority in resolving disputes over the election results, it is an early indication that many judicial institutions are given the power to adjudicate disputes in implementing the general election, which inevitably causes overlapping authorities and decisions that trigger disputes over sovereignty between the State institutions.

\section{The Choice of Judicial Institutions as an Embodiment of Integration of Authorities to Adjudicate Election Issues}

The transfer of authority to adjudicate all problems in administering general elections to a judicial institution can be realized by giving it to an existing judicial institution. In this case, it is between the Supreme Court and the Constitutional Court. Even though the gift to one of the two judicial institutions still contains or has problems.

If sent to the Constitutional Court, it will cause problems juridically and sociologically. Juridically, the Constitutional Court does not have the authority to adjudicate general election issues. The Constitutional Court's authority regarding general elections is explicitly limited to adjudicating cases of election result disputes. The Constitutional Court's authority is limited to disagreements over the collected votes from the election results. If the Constitutional Court is given the authority to adjudicate the general election process from beginning to end, the Court will become an institution that exceeds its authority. However, this juridical problem can be put aside if an amendment is made to Article 24C of the 1945 Constitution of the Republic of Indonesia concerning the Constitutional Court's fourth authority. In terms of the 
fourth Constitutional Court's control, a change must be made from "the constitutional court has the authority to adjudicate election results disputes" to "the constitutional court has the authority to adjudicate problems that occur in the implementation of general elections."

Sociologically, if the authority to judge all problems in implementing the general election is given to the Constitutional Court. In that case, they will not produce a decision that is considered true based on trial facts and evidence studied carefully and seriously considering the number of constitution judges, which is only nine. It is impossible to be able to judge appropriately on all problems that exist in the general election. Their composition and the limitation of completion time in holding the general election are certainly not proportional. An example can be taken in cases submitted and tried by the Constitutional Court in the 2004, 2009, 2014 general elections. For the 2004 legislative elections, the Constitutional Court tried 44 cases within 30 days. Besides, in the 2009 general election, they tried 70 cases within 30 days. While, in the 2014 general election, they also tried 296 cases.

Table 2. The Number of Dispute Cases in General Election Results (source: MKRI, 2019)

\begin{tabular}{|c|c|c|c|c|c|}
\hline \multirow[t]{2}{*}{ No } & \multirow[t]{2}{*}{ General Election Period } & \multicolumn{4}{|c|}{ Number of Cases } \\
\hline & & $\begin{array}{l}\text { Legislative } \\
\text { Election }\end{array}$ & General & $\begin{array}{l}\text { Presidential } \\
\text { Election }\end{array}$ & General \\
\hline 1 & 2004 General Election & 44 & & 1 & \\
\hline 2 & 2009 General Election & 70 & & 2 & \\
\hline 3 & 2014 General Election & 296 & & 1 & \\
\hline 4 & 2019 General Election & 251 & & 1 & \\
\hline
\end{tabular}

On the other hand, the Constitutional Court also has powers beyond its authority to adjudicate general election issues. The Constitutional Court has the authority to examine laws against the constitution, adjudicate disputes over the control of state institutions whose authority is given by the constitution, the dissolution of political parties, and the Constitutional Court is obliged to decide on the opinion of the DPR regarding the impeachment of the President / Vice President. Therefore, when the Constitutional Court is given the authority as the only election court institution, it will make the Constitutional Court unable in terms of the number of human resources and the amount of time it has to adjudicate Election problems. Even if it is imposed on the Constitutional Court, it will lose its identity to carry out the Constitutional Court's foremost authority, namely the constitutional norm or as a judicial institution that examines the constitutionality of government legal actions or legislators (Siahaan, 2009).

Meanwhile, if given to the Supreme Court, it becomes legitimate considering Article 24 of the 1945 Constitution of the Republic of Indonesia concerning the 
Supreme Court's authority. They have the authorization to adjudicate other issues provided by law. This means that this is an entry point to make the Supreme Court the only judicial institution for all problems in administering the general election. At this level, one can establish a special court to help elections such as the corruption court, juvenile court, industrial relations court, tax court, sharia court, fishery court, and others (Spaltani, 2018).

The judiciary that will be formed under the Supreme Court's auspices can be given the authority to adjudicate all the election process problems, from the nomination process to disputes over the election results. However, something must be ascertained in advance if a special election judiciary institution is to be formed under or within the Supreme Court regarding the nature of the institution's decision. If the special judiciary is under the Supreme Court, the institution will automatically have a hierarchical relationship between institutions and decisions. One means that the special electoral judiciary body is not a judicial institution at the first or last instance. Its decisions are final and binding because, as a judicial institution under the Supreme Court, the special election judiciary's decisions can automatically be compared and judged.

The problems that will arise if the special electoral judiciary decisions can be compared and cases will result in incremental legal decisions related to election problems that will drag on. It is very unlikely that the Election problem is a special problem that must be tried quickly. However, this problem is straightforward to overcome by giving the authority to the special judiciary that will be formed as the first and last level judicial institutions whose decisions are final and binding to adjudicate problems in implementing the election. It is possible because it depends on how it is regulated in the law that will be formed.

Apart from the debate whether the new institution that specifically adjudicates general election issues will be under the Supreme Court or stand-alone and independently, the presence of a special judiciary in general election issues will have various positive implications in the form of;

First, the concern that there will be different decisions between judicial institutions in solving general election problems can be avoided because the judicial process is in one branch of the judiciary (Al-Fatih, 2018).

Second, in the Indonesian context, the problem of overlapping authorities of state institutions has a huge potential (Fitryantica, 2019). The difference between the Supreme Court and the Constitutional Court decisions and the conflict between the police authorities and the Corruption Eradication Commission are concrete evidence. With the existence of a special judicial institution that is given the authority to adjudicate the entire process of solving election problems in one Court/Judiciary Body, it can avoid the impression of a state institution claiming or feeling that its authority is being alienated (castrated). It means that a state institution considers that 
the authority that should be an authority owned by the institution but was taken over by another institution.

Third, there is no need to worry that the judicial process on general election problems will time-consuming (Al-Fatih, 2019). It considers that one institution's judicial process will resolve general election problems sequentially and systematically or not in conflict with other processes usually carried out by different institutions even though the issues being tried are interrelated.

Meanwhile, the argument stating that under one branch judiciary process is timeconsuming cannot be put forward. This is because the implementation of the general election is regulated in a recurring schedule. The phases based on scheduling certainly explain that when there are problems in determining the vote count results, the problem is no longer during deciding candidates. It means that if you have entered into a dispute over the general election results, the special election court will only focus on the issue of disputes over the results. In contrast, determining the pair of candidates and the campaign has passed or the time for trial. This means that the dispute regarding the determination of the pairs of candidates participating in the election by the General Elections Commission has been completed as well as the judicial process in the event that the lawsuits of the pairs of candidates that are not passed also cannot be carried out because they have exceeded the time limit.

Fourth, special courts in adjudicating election issues are necessary because of elections' independent spirit (Asshiddiqie, 2013). It means that the general election's implementation is a democratic process that must run without any intervention from any interests, including the authorities' political claims. Therefore, the general election's performance from the process stage to the election results' determination must run without interest, especially when there are disputes related to the implementation. When the judicial process problems in the general election are handled by institutions that can intervene or have the potential to be intervened by certain parties. The implementation of a free and fair election is questionable. The presence of a special judiciary in general election matters ensures that the performance is independent and specific primarily because it is directly related to the guarantee of the freedom to exercise people's sovereignty.

Fifth, in the principle of ius curia novit: when the judicial process on the general election problems is integrated into one judicial institution, it will make the decision incorrect (Amalia et al., 2019). It is because of doubts that the judge understands all the problems in the election. It cannot be raised considering that, for judges, the principle of ius curia novit applies. The principle of ius curia novit means that the judge is deemed to know. This principle becomes the basis for ensuring that when the election dispute resolution process is integrated in one judicial institution, the judicial process will be based on the principles of truth, justice, and legal certainty. This is because the 
judges in the single electoral judiciary can be drawn from various backgrounds who have competence in the legal construction of election administration.

\section{CONCLUSION}

Regulations regarding the authority to adjudicate general election issues are given to the Constitutional Court to adjudicate election result disputes. Then the Supreme Court is to adjudicate election administration violations. The State Administrative Court functions to adjudicate the general election process disputes and the District Courts and the High Courts to adjudicate criminal election violations. The handover of the authority to judge general election issues to the four judicial institutions has made resolving its problems into a judicial process that is not following fast and straightforward judicial principles. It is necessary to integrate the authority to adjudicate all issues to one judicial institution. The authority to judge all election problems can be given to the Constitutional Court, the Supreme Court, or the Special Courts. The Special Judicial Institution can be under or within the Supreme Court or independently.

\section{ACKNOWLEDGMENTS}

Many thanks are addressed to the Rector of University of Islam Malang and all parties for their countless assistant in completing this service report.

\section{REFERENCES}

Al-Fatih, S. (2020). Electoral Regulation in Indonesia : Is It Modern Law ? Unnes Law Journal, 6(2), 205-216. https://doi.org/https://doi.org/10.15294/ulj.v6i2.41627

Al-Fatih, S. (2018). Model Pengujian Peraturan Perundang-Undangan Satu Atap Melalui Mahkamah Konstitusi. Jurnal Ilmiah Hukum LEGALITY, 25(2), 247. https://doi.org/10.22219/jihl.v25i2.6005

Al-Fatih, S. (2019). Akibat Hukum Regulasi tentang Threshold dalamPemilihan Umum Legislatif dan Pemilihan Presiden: Kajian Putusan Mahkamah Konstitusi Nomor 52/PUU-X/2012 dan Nomor 14/PUU-XI/2013. Jurnal Yudisial, 12(1), 17-38. https://doi.org/10.29123/jy.v12i1.258

Al-Fatih, S., Safaat, M. A., \& Dahlan, M. (2014). Reformulasi Parliamentary Threshold Yang Berkeadilan Dalam Pemilu Legislatif Di Indonesia. Jurnal Hukum, 20.

http://hukum.studentjournal.ub.ac.id/index.php/hukum/article/view/1018/10 07

Amalia, R. A., Wibowo, G. D. H., \& Kaharudin. (2019). Konflik Asas Ius Curia Novit Dengan Asas Nemo Judex in. Education and Development, 7(3), 224-227. https://doi.org/https://doi.org/10.37081/ed.v7i3.1240

Asshiddiqie, J. (2013). Pengadilan Khusus, Dalam Hitam Putih Pengadilan Khusus. Sekretariat Komisi Yudisial Republik Indonesia.

Assistance, E. (2011). Strengthening the roles of political parties in public accountability.

Cahyandari, D., Siboy, A., \& Sudarsono, S. (2020). Urgensi Pemisahan Kewenangan Mengadili Perselisihan Hasil Pemilihan Umum Serentak. Arena Hukum, 13(01), 
59-76. https://doi.org/10.21776/ub.arenahukum.2020.01301.4

Elliott, R., \& Timulak, L. (2015). Descriptive and interpretive approaches to qualitative research. In J. M. and P. Gilbert (Ed.), A Handbook of Research Methods for Clinical and Health Psychology (pp. 147-157). Oxford University Press. https://doi.org/10.1093/med:psych/9780198527565.001.0001

Esfandiari, F., \& Fatih, S. Al. (2020). Initiating a Permanent Electoral Body To Resolve Dignified Election Disputes: Assessing the Effectiveness of Gakkumdu. Yustisia Jurnal Hukum, 9(3), 333. https://doi.org/10.20961/yustisia.v9i3.44437

Fitryantica, A. (2019). Harmonisasi Peraturan Perundang-Undangan Indonesia melalui Konsep Omnibus Law. Gema Keadilan, 6(3), 300-316. https://doi.org/10.14710/gk.6.3.300-316

Harun, R. (2015). Rekonstruksi Kewenangan Penyelesaian Perselisihan Hasil Pemilihan Umum. Jurnal Konstitusi, 13(1), 1-24.

Leuprecht, C., \& Skillicorn, D. B. (2016). Incumbency effects in U.S. presidential campaigns: Language patterns matter. Electoral Studies, 43, 95-103. https://doi.org/10.1016/j.electstud.2016.05.008

Liany, L. (2016). Desain Hubungan Kelembagaan Penyelenggara Pemilu. Jurnal Cita Hukum, 4(1), 51-72. https://doi.org/10.15408/jch.v4i1.3198

Luttig, M. D., \& Motta, M. (2017). President Obama on the ballot : Referendum voting and racial spillover in the 2014 midterm elections. Electoral Studies, 50, 80-90. https://doi.org/10.1016/j.electstud.2017.09.009

MKRI. (2019). Rekapitulasi Perkara Perselisiban Hasil Pemiliban Umum. Mahkamah Konstitusi Republik Indonesia.

Momeni, N. (2012). Linguistic recontextualization of police interrogation: a new approach in Forensic Linguistics. 5(1), 796-807.

Olsson, A., \& Meek, L. (2013). Effectiveness of Research and Innovation Management at Policy and Institutional Levels. In Innovation, Higher Education and Research for Development: Vol. interconti.

Pal, J., \& Gonawela, A. (2017). Studying political communication on Twitter: the case for small data. Current Opinion in Behavioral Sciences, 18, 97-102. https://doi.org/10.1016/j.cobeha.2017.09.009

Pennisi, G. A. (2016). Legislative drafting and language: Legal language in context. Statute Law Review, 37(2), 97-100. https://doi.org/10.1093/slr/hmw024

Peter Mahmud Marzuki. (2014). Penelitian Hukum. Kencana Prenada Media Group. republik indonesia. (2017). Undang-Undang nomor 7 tahun 2017 Tentang Pemilu. Undang-Undang Pemilu.

Ridwan. (2009). Tiga Dimensi Hukum Administrasi dan Peradilan Administrasi. FH UII Press.

Schane, S. (2002). Ambiguity and Misunderstanding in the Law. Thomas Jefferson Law Review, 25(1960), 167-182.

Siahaan, M. (2009). Peran Mahkamah Konstitusi dalam Penegakan Hukum Konstitusi. Jurnal Hukum Ius Quia Iustum, 16(3), 357-378.

Siahaan, M. (2011). Hukum Acara Mabkamah Konstitusi Republik Indonesia. Sinar Grafika.

Sinha, S. (2015). Forensic linguistics and forensic phonetics: An introduction. Journal 
of Interdisciplinary and Multidisciplinary Research, 2(6), 153-157.

Soekanto, S., \& Mamudji, S. (2010). Penelitian Hukum Normatif Suatu Tinjauan Singkat. Raja Grafindo Persada.

Soemaryono, \& Erliyana, A. (1999). Tuntutan Praktek Beracara di Peradilan Tata Usaha Negara. PT. Pramedya Pustaka.

Spaltani, B. G. (2018). Urgensi Pengadilan Khusus Dalam Penegakan Hukum Lingkungan

Di Indonesia. Universitas Muhammadiyah Surakarta.

Wiyono, R. (2008). Hukum Acara Peradilan Tata Usaha Negara. Penerbit Sinar Grafika. Yuslim. (2015). Hukum Acara Peradilan Tata Usaba Negara. Sinar Grafika. 